\title{
EFFECT OF TRICKLE IRRIGATION ON ROOT DEVELOPMENT OF THE WET BULB AND 'PERA' ORANGE TREE YIELD IN THE STATE OF SÃO PAULO, BRAZIL
}

\author{
REGINA C. DE M. PIRES ${ }^{1}$, DÉCIO BODINE JUNIOR ${ }^{2}$, EMÍLIO SAKAI ${ }^{1}$, \\ HELOÍSA L. VILLAR ${ }^{3}$, TONNY J. A. DA SILVA ${ }^{4}$, FLÁVIO B. ARRUDA ${ }^{1}$
}

\begin{abstract}
The aim of this study was to evaluate the effect of different microirrigation designs on root system distribution in wet bulb region, orange orchard yield and quality of orange fruits. The experiment was installed as random blocks with five treatments and four replicates in an orchard of 'Pêra' orange trees grafted on 'Cleopatra' mandarin rootstock. The treatments consisted of: one drip line (T1), two drip lines (T2), four drip lines (T3) per planting row, microsprinkler irrigation (T4) and without irrigation (T5). Irrigation treatments favored yield and ${ }^{\circ}$ Brix. The treatment with a single drip line (T1) showed the greatest quantity of roots in relation to the treatments $\mathrm{T} 2$ and $\mathrm{T} 3$.
\end{abstract}

KEYWORDS: trickle irrigation, microsprinkler irrigation, citrus, water management.

\section{EFEITO DA IRRIGAÇÃO LOCLIZADA NO DESENVOLVIMENTO RADICULAR NO BULBO ÚMIDO E PRODUÇÃO DA LARANJEIRA-PERA NO ESTADO DE SÃO PAULO, BRASIL}

RESUMO: O objetivo do presente trabalho foi avaliar o efeito de diferentes configurações da irrigação localizada na distribuição do sistema radicular na região do bulbo úmido, na produção e na qualidade dos frutos de laranjeira. $\mathrm{O}$ experimento foi instalado em blocos ao acaso, com cinco tratamentos e quatro repetições, em pomar de plantas adultas de laranjeira-Pera enxertada em tangerina-Cleópatra. Os tratamentos consistiram em parcelas com uma linha de tubogotejador (T1), duas linhas de tubogotejadores (T2), quatro linhas de tubogotejadores (T3) por linha de plantio, microaspersão (T4) e sem irrigação (T5). Os tratamentos irrigados favoreceram a produção e o teor de ${ }^{\circ}$ Brix. Observou-se maior concentração de raízes na região do bulbo úmido no T1 em relação ao T2 e ao T3.

PALAVRAS-CHAVE: irrigação por gotejamento, microaspersão, cítrus, manejo da água.

\section{INTRODUCTION}

The Brazilian citrus industry is the largest producer and exporter of frozen concentrated juice in the world (FAO, 2006). The State of São Paulo is the largest producer of citrus in Brazil representing approximately $80 \%$ of the total production in the country (SAA/CATI/LUPA, 2009).

Irrigation and crop management techniques in the Brazilian citrus orchards started in the early 60 's to produce fruit for fresh consumption due to improvement in quality and productivity. In the early 90's, irrigation in the citrus industry began to be employed also in fruit orchards destined for juice production. Due to positive results, the irrigated area for production of fruit for juice grew larger than that for table fruit production. According to industry production estimations, in 1999 only $1.5 \%$ of cultivated orchards in São Paulo were irrigated. After a little more than a decade, in 2006 the irrigated area of 90,000 ha was representing about $15 \%$ of the cultivated area (FNP, 2007). Currently, according to information from manufacturers of irrigation equipment, the irrigated area

\footnotetext{
${ }^{1}$ Engenheiros Agrônomos, Pesquisadores Científicos, Centro de Ecofisiologia e Biofísica, Instituto Agronômico (IAC), Caixa Postal 28, Campinas, SP, Brasil, rcmpires@iac.sp.gov.br.

${ }^{2}$ Biólogo, Syngenta.

${ }^{3}$ Bióloga, Estagiária do Centro de Ecofisiologia e Biofísica, Instituto Agronômico (IAC).

${ }^{4}$ Professor, Universidade Federal do Mato Grosso - MT.

Recebido pelo Conselho Editorial em: 15-9-2009
}

Aprovado pelo Conselho Editorial em: 15-8-2011 
exceeds $20 \%$ of total citrus cultivation. Due to occurrence of disease problems in São Paulo orchards and the consequent need for replacement for resistant and/or tolerant rootstocks that are sensitive to water stress (POMPEU JUNIOR, 2005); the use of irrigation is necessary, especially in northern and central state. Thus, irrigation is an important practice in the production process to achieve high yields. It should also be noted that in regions where citrus is concentrated in São Paulo, there is no water available for unreservedly expansion of irrigation and without the adoption of technical standards. In this restrictive scenario, trickle irrigation has been strongly recommended and adopted, since the reduction of water usage also allows savings of energy and labor and facilitates fertigation and automation. To implementing trickle irrigation in citrus, some aspects are fundamental and require investigation (BARBOZA et al., 2008). One of them is the evaluation of different wet areas provided by trickle irrigation, since it strongly influences the cost of the irrigation system.

In the U.S., SMAJSTRLA \& KOO (1984) observed that when irrigation is supplemental to rainfall in adult plants, and especially in sandy soils, about $50 \%$ of the root system must be irrigated. General information for citrus irrigation in Spain says, according to CASTANER (1993), that the wet area should be around $40 \%$. In Florida, microsprinkling is recommended to provide frequent irrigation with high water usage efficiency and possibility of prevention and protection from frosts (PARSONS \& WHEATON, 2000). In Brazil, ZANINI et al. (1998) recommend that, in adult plants of citrus, water should be about $50 \%$ of the total area available to the plants or at least the projection area of the crown. COELHO et al. (2000) suggest, for citrus, values between 33 and $67 \%$ of the wet area. However, the authors point out that in regions with annual rainfall above $1200 \mathrm{~mm}$, lower values may be adopted. SOUZA et al. (2003) found no effect of 15, 31 and 46\% wet area in Tahiti lime production in the conditions of the municipality of Visconde do Rio Branco, state of Minas Gerais. In large areas of commercial citrus cultivation in Brazil, percentage values of wet area between 10 and $20 \%$ have been adopted. In this context, increases in average production of about 20 to $55 \%$ have been achieved (PIRES et al., 2005).

The efficiency and success of irrigation in citrus, where only part of the soil surface is wet has been demonstrated in different cultivation regions. For these systems, the percentage of wet soil consists of an important parameter and must be associated with irrigation management and fertigation conditions. In this context, the adaptation of plant roots to irrigation is essential to obtain satisfactory results. In many cases, the adoption of practices and standards for water irrigation management has been based on experience of other countries with different genetic material, climate, soil, and crop management. It is worth emphasizing the need of investigation for the different ecological conditions of cultivation and crop management of Brazilian citrus. Given this context, this study aimed to evaluate the use of different irrigation system configurations (trickle and microsprinkling) on root distribution of irrigated plants in the region of the wet bulb, and the possible effects on yield and quality of orange fruit.

\section{MATERIAL AND METHODS}

The experiment was established in June 2006, in a commercial cultivation area with an orchard containing orange tree cv. 'Pêra' grafted onto 'Cleopatra' mandarin, planted in 1992 in the municipality of Casa Branca, State of São Paulo, Brazil. The plants were spaced $8 \mathrm{~m}$ between rows of $3 \mathrm{~m}$ between plants in the row. The experiment was conducted in randomized blocks with five treatments and four replications. Plots consisted of 21 plants, with three rows of seven plants each, with only the five central plants considered. The experimental area was of approximately 1 ha.

To characterize the soil and the suitability of fertilization and fertigation, chemical and physical analyses of the soil were carried out. The soil was classified as medium-texture RedYellow Oxisol. According to the model proposed by GENUCHTEN (1980), the curve of water retention in the soil, with the average of the soil profile from surface to a depth of $0.60 \mathrm{~m}$, resulted in the equation below: 


$$
\theta=0.134+\frac{0.304-0.101}{\left[1+(0.0339 .|\phi|)^{2.4672}\right]^{0.1045}}
$$

where,

$\theta$ - soil humidity based in volume, and

$\phi$ - water potential in the soil, cm wc.

Samples for chemical analysis of the soil were taken from beneath the crown of the plants before starting the experiment. Fertilizer distribution considered the developmental stage of culture. On October 26, 2006 the first conventional fertilization of the crop was held in all treatments with application of solid fertilizer in the 20-05-15 formulation with a dosage of $235.2 \mathrm{~kg} \mathrm{ha}^{-1}$. On January 25, 2007, new fertilization in all treatments was performed, consisting of application of $76 \mathrm{~kg} \mathrm{ha}^{-1}$ potassium nitrate, $70.9 \mathrm{~kg} \mathrm{ha}^{-1}$ calcium nitrate, $50.6 \mathrm{~kg} \mathrm{ha}^{-1}$ magnesium sulfate and $60.7 \mathrm{~kg} \mathrm{ha}^{-1}$ of manganese sulfate. Fertigation was performed weekly with soluble fertilizers (from Jaraguá Agrícola Fertilizantes Solúveis). The following soluble fertilizers were applied: Maxsol 1610-28, Maxsol 19-04-19, and calcium nitrate, totaling from February to May 2007, 374.1, 98 and $61.4 \mathrm{~kg} \mathrm{ha}^{-1}$, respectively. Formulations and calcium nitrate were distributed according to the developmental stage of the plant. In non-irrigated treatments, between the first fertilization and the end of April 2007, there had been four applications of solid fertilizers, with $235.2 \mathrm{~kg} \mathrm{ha}^{-1}$ of the formula 20-05-15, 470.4 $\mathrm{kg} \mathrm{ha}^{-1}$ of 20-05-10 and $126 \mathrm{~kg} \mathrm{ha}^{-1}$ of potassium chloride. On January 19, 2007 , liming was applied in the experimental area, with a total dose of 4 ton $\mathrm{ha}^{-1}$. For the crop year 2007-2008, fertigation in the irrigated treatments began on August 25, 2007 and was performed weekly after the apparent "rest" period of the orange trees (MEDINA et al., 2005). In the irrigated treatments, between August 25 and January 4, 2008, $77.1 \mathrm{~kg} \mathrm{ha}^{-1} \mathrm{~N}, 35.3 \mathrm{~kg} \mathrm{ha}^{-1} \mathrm{P}$ and $141.6 \mathrm{~kg} \mathrm{ha}^{-1}$ $\mathrm{K}$ were applied. For fertigation, the formulations Maxsol 16-10-28, 12-06-37, 19-04-19 and calcium nitrate were used. In the same period, fertilization of the non-irrigated treatment used $133 \mathrm{~kg} \mathrm{~N} \mathrm{ha}^{-1}$, $46.5 \mathrm{~kg} \mathrm{ha}^{-1} \mathrm{P}$ and $92.9 \mathrm{~kg} \mathrm{ha}^{-1} \mathrm{~K}$, with the formula 20-07-14. The difference in application between the irrigated and the non-irrigated treatments results from the mismatch in the application time, but by the end of the season, the nutrients levels used were comparable.

The treatments were implemented as follows: one dripping tube per planting line (emitters spaced every $0.60 \mathrm{~m}$ ) (T1), two dripping tubes per planting line (emitters every $0.90 \mathrm{~m}$ ) (T2), four dripping tubes per planting line (emitters every $1.10 \mathrm{~m}$ ) (T3), and micro sprinkler irrigation (one emitter per plant) (T4), and a non-irrigated control (T5). The nominal flow rate of emitters used in $\mathrm{T} 1, \mathrm{~T} 2$ and T3 was $3.5 \mathrm{~L} \mathrm{~h}^{-1}$. The emitter was installed $0.20 \mathrm{~m}$ from the plant's stem with a nominal flow of $50 \mathrm{~L} \mathrm{~h}^{-1}$. The wet area provided by T1, T2, T3 and T4 was 8, 10.6, 17.5 and $29 \%$ over the total area, and 11.5, 15.1, 42.1 and $25 \%$ considering the projection area of the tree canopy.

To monitor and make necessary adjustments during the irrigation management, tensiometers were installed at depths of $0.30,0.60$ and $0.90 \mathrm{~m}$ to ensure that the soil water potential was always kept within desirable limits to maintain adequate water consumption of the plants in the potential condition, considering after irrigation, the water in the soil was within the upper limit of soil water retention (PIRES et al., 2005) with the completion of daily irrigations to a depth of $0.60 \mathrm{~m}$. Irrigation control was performed in accordance with tensiometer measurements. To monitor soil moisture, a model DIVINER2000 was used to probe high-frequency capacitance (FARES et al., 2004). To perform measurements of soil moisture by probing, access PVC tubes were installed. It was performed calibration of the probe capacitance in the soil of the experimental area. In trickle irrigated treatments, access tubes were installed in the direction of the rows, $0.15 \mathrm{~m}$ from the dripper and located between $1 / 3$ to $2 / 3$ radiuses of the tree crown (PIRES et al., 2005). In the treatment irrigated by microsprinkler, pipes were installed in the same position in relation to the plant and about 0.80 to $1.0 \mathrm{~m}$ from the emitter. In the treatment without irrigation, pipes were installed in the same position in relation to plants. Measurements of soil moisture were taken every $0.1 \mathrm{~m}$ to a depth of $1.0 \mathrm{~m}$. Three access tubes were installed per treatment. 
In 2006, irrigation began Sept. 12, after the apparent rest period of citrus. Irrigation was performed daily except on rainy days and some subsequent days, according to the rainfall volume. Irrigation was resumed in early March 2007 and continued to be applied daily until May 25, 2007. From this date, irrigation was suspended for the period of apparent rest citrus. In the new agricultural cycle, irrigation was reset daily from August 25. For monitoring the climate, an automatic weather station was installed near the experimental area. The reference evapotranspiration was estimated by the Penman-Monteith method (ALLEN et al., 1998).

Root length in the region of the wet bulb was estimated on August 19, 2007 using the method proposed by MARSH (1971) and TENNANT (1975), in T1, T2 and T3, eleven months after the irrigation started. Trenches were opened perpendicularly to the plant line, with a 1-m distance from the plant's trunk. Trenches were opened up to $0.50 \mathrm{~m}$ depth, since the root system was not visualized below $0.40 \mathrm{~m}$; they were $1.3 \mathrm{~m}$ long on each side of the plant, according to the dripping outline. Roots were exposed using wooden rods. The roots present in the trench were painted white for better visibility and a $0.05 \times 0.05 \mathrm{~m}$ grid was placed. Subsequently, visual counting of the number of root intersections in the grid was performed. The grid was installed in order to evaluate $0.30 \mathrm{~m}$ on each side of the dripper in all drippers of each experimental treatment, with two replicates per treatment.

Harvest of the 2006/2007 cycle occurred on September 12-13, 2007. Fruits were collected from five useful plants of each plot and weighed. Fifty fruits were sampled to estimate the number and weight of fruits per plot, and sent to the laboratory for analysis of juice quality traits. The results were subjected to analysis of variance by the F-test and the means were compared by Duncan's test at 5\% probability (PIMENTEL-GOMES \& GARCIA, 2002).

\section{RESULTS AND DISCUSSION}

Table 1 shows the results of chemical analysis of the soil. According to these results, it is noticed that fertility was typical for the development of the crop, with average levels of potassium, magnesium and index base saturation (V\%), and high for phosphorus and calcium (RAIJ et al., 1997; QUAGGIO et al., 2005).

TABLE 1. Results of soil chemical analysis before implantation of the irrigation system in the cultivated area with Pêra orange trees, in Casa Branca, state of São Paulo, Brazil.

\begin{tabular}{|c|c|c|c|c|c|c|c|c|c|c|}
\hline \multirow{2}{*}{$\begin{array}{c}\text { Depth. } \\
\text { (m) }\end{array}$} & \multicolumn{2}{|c|}{$\mathrm{pH}$} & \multirow{2}{*}{$\begin{array}{l}\text { O.M. } \\
\mathrm{g} \mathrm{dm}^{-3}\end{array}$} & \multirow{2}{*}{$\begin{array}{c}\mathrm{P} \\
\left(\mathrm{mg} \mathrm{dm}^{-3}\right)^{*}\end{array}$} & $\mathrm{~K}$ & $\mathrm{Ca}$ & $\mathrm{Mg}$ & $\mathrm{Al}+\mathrm{H}$ & CEC & $\mathrm{V}$ \\
\hline & $\mathrm{CaCl}_{2}$ & $\mathrm{H}_{2} \mathrm{O}$ & & & \multicolumn{5}{|c|}{ mmolc $\mathrm{dm}^{-3}$} & $\%$ \\
\hline $0.0-0.1$ & 5.3 & 6.0 & 24.0 & 69.0 & 2.30 & 22.0 & 7.0 & 24.0 & 55.3 & 56.6 \\
\hline $0.1-0.2$ & 5.1 & 5.8 & 21.0 & 67.0 & 2.40 & 15.0 & 5.0 & 25.0 & 47.4 & 47.3 \\
\hline $0.2-0.4$ & 5.2 & 6.0 & 15.0 & 48.0 & 2.50 & 16.0 & 6.0 & 24.0 & 48.5 & 50.5 \\
\hline
\end{tabular}

* Anion resin

The results of physical analysis of the Oxisol are in Table 2. According to the results, it is noticed that the soil is classified as medium texture at all depths evaluated. There was an increase in the density of the soil layer from 0.1 to $0.2 \mathrm{~m}$.

TABLE 2. Particle size distribution and soil and particles densities of cultivated area with Pêra orange trees, in Casa Branca, state of São Paulo, Brazil.

\begin{tabular}{ccccccc}
\hline \multirow{2}{*}{ Depth } & \multicolumn{2}{c}{ Sand } & \multirow{2}{*}{ Silt } & Clay & \multicolumn{2}{c}{ Soil Density } \\
\cline { 2 - 4 } & coarse & fine & & & \multicolumn{2}{c}{$\mathrm{kg} \mathrm{m}^{-3}$} \\
\hline $\mathrm{m}$ & & \multicolumn{2}{c}{$\mathrm{kg} \mathrm{m}^{-3}$} & & & \\
$0.0-0.1$ & 220 & 260 & 250 & 270 & 1400 & 2270 \\
$0.1-0.2$ & 450 & 160 & 110 & 280 & 1550 & 2470 \\
$0.2-0.3$ & 370 & 210 & 110 & 310 & 1380 & 2380 \\
$0.3-0.6$ & 420 & 210 & 70 & 300 & 1270 & 2470 \\
\hline
\end{tabular}


Figure 1 shows estimative of root length per wet bulb at different depths and distances from the dripper in T1, T2 and T3. The T1 has fewer emitters per plant, and therefore with less wetted area provided by the drip, it showed the highest number of roots in the wet bulb region. This fact possibly justifies the good performance of irrigated orchards in São Paulo with only one dripper per line, as reported by Pires et al. (2005), and it agrees with the results reported by SHALHEVET \& LEVY (1990). It should be noted that this must also be associated with the daily frequency of irrigation. It appears that in all treatments, root concentration was greater between 0.10 to $0.30 \mathrm{~m}$ from the dripper, corroborating results reported by ABREU \& SALVIANO (2007). This information is important for installation of sensors to monitor soil humidity.

Table 3 shows the distribution and cumulative percentage of roots with depth in different treatments. According to the values obtained, it is observed that about $80 \%$ of the roots were present in the wet bulb up to 0.20 to $0.25 \mathrm{~m}$ deep. Although the results obtained in Table 3 are only in the region of the wet bulb, they are similar to those observed by COELHO et al. (2002) in three different citrus rootstocks, and by ALVES JUNIOR et al. (2004) in young plants of Tahiti lime. On the other hand, TESTEZLAF et al. (2007) and ABREU \& SALVIANO (2007) found 80 to $90 \%$ of the roots of adult orange plants grafted on 'Rangpur' lime up to $0.4 \mathrm{~m}$ deep. In sandy soil conditions in Florida, MORGAN et al. (2006) found high concentration of citrus roots up to $0.15 \mathrm{~m}$ deep. For purposes of water management and fertigation, assessing root depth distribution and in the wet bulb is critical to monitoring, control and evaluation of the technique. According to Tables 1 and 2, small variations in the values observed in relation to chemical and physical soil at different depths evaluated should not have influenced root development.

TABLE 3. Distribution and accumulated percentages of root system of Pêra orange trees grafted on Cleopatra mandarin rootstock in different treatments: (T1) one drip line, (T2) two drip lines and (T3) four drip lines per planting row, in different depths, in Casa Branca, state of São Paulo, Brazil.

\begin{tabular}{ccccccc}
\hline \multirow{2}{*}{$\begin{array}{c}\text { Depth } \\
(\mathrm{m})\end{array}$} & \multicolumn{5}{c}{ Distribution of root system length (\%) } \\
\cline { 2 - 7 } & $\%$ & T1 & \multicolumn{3}{c}{ T2 } & T3 \\
\hline $0.0-0.05$ & 19.0 & 19.0 & 14.7 & 14.7 & 20.1 & accumulated \% \\
$0.05-0.10$ & 27.2 & 46.2 & 29.1 & 43.8 & 25.0 & 45.1 \\
$0.10-0.15$ & 20.8 & 67.0 & 19.2 & 63.0 & 16.8 & 61.9 \\
$0.15-0.20$ & 13.7 & 80.7 & 12.8 & 75.8 & 14.4 & 76.3 \\
$0.20-0.25$ & 9.6 & 90.3 & 10.7 & 86.5 & 11.9 & 88.2 \\
$0.25-0.30$ & 4.6 & 94.9 & 6.9 & 93.4 & 7.1 & 95.3 \\
$0.30-0.35$ & 5.1 & 100.0 & 6.6 & 100.0 & 4.7 & 100.0 \\
\hline
\end{tabular}

Table 4 shows the results of plant yield, average fruit weight, ratio and ${ }^{\circ}$ Brix obtained in different treatments in samples harvested in September 2007. All irrigated treatments favored production of fruits per plant compared to non-irrigated, with an increase higher than $100 \%$. The largest area wetted by irrigation did not favor yield (Table 4). Possibly, root development in wet bulb in T1 (Figure 1) was already sufficient to find the plants' water and nutritional needs. This fact allows reducing the costs of the irrigation system. Importantly, chemical monitoring of the soil by evaluating the soil solution should be intensified in the region of the wet bulb to ensure proper condition for root development, especially with the wet conditions concentrated in smaller areas with intense root concentration, as shown in Figure 1. Positive results by the adoption of irrigation in citrus orchards in São Paulo, Brazil were also observed by BARRETO et al. (1976); ZANINI \& PAVANI (1998); ALVES JUNIOR et al. (2004). It is noteworthy that the largest wetted area by irrigation did not favor the production of fruits per plant, unlike reported by SMAJSTRLA \& KOO (1984), ZANINI et al. (1998) and COELHO et al. (2000). This fact is possibly associated with daily irrigation frequency adopted in this study. The association of wet area and irrigation frequency was 
also discussed by BIELORAI (1977), quoted by SHALHEVET \& LEVY (1990) to obtain similar production when $30 \%$ of the irrigated area every three days, compared to $70 \%$ of irrigation area every seven days. However, these authors adopted larger intervals between irrigations than the present study. SOUZA et al. (2003) also observed no significant differences in the production of Tahiti lime when adopting different percentages of wet area in the conditions of the Visconde do Rio Branco, in the state of Minas Gerais, Brazil, confirming the results obtained in this study (Table 4).

TABLE 4. Fruit yield $\left(\mathrm{kg}_{\text {plant }}{ }^{-1}\right)$; mean fruit weight $\left(\mathrm{kg}\right.$ fruit $\left.{ }^{-1}\right)$, Ratio, and ${ }^{\circ}$ Brix of Pêra orange trees, cultivated in Casa Branca, state of São Paulo, Brazil.

\begin{tabular}{ccccc}
\hline Treatments & Production & Mean fruit weight & Ratio & ${ }^{\circ}$ Brix \\
\hline T1 & $80.7 \mathrm{a}$ & $0.151 \mathrm{ab}$ & $13.4 \mathrm{~b}$ & $12.2 \mathrm{ab}$ \\
T2 & $81.6 \mathrm{a}$ & $0.132 \mathrm{~b}$ & $13.6 \mathrm{~b}$ & $12.5 \mathrm{a}$ \\
T3 & $87.9 \mathrm{a}$ & $0.160 \mathrm{ab}$ & $13.2 \mathrm{~b}$ & $12.2 \mathrm{ab}$ \\
T4 & $90.3 \mathrm{a}$ & $0.138 \mathrm{~b}$ & $13.1 \mathrm{~b}$ & $12.2 \mathrm{ab}$ \\
T5 & $36.4 \mathrm{~b}$ & $0.171 \mathrm{a}$ & $14.2 \mathrm{a}$ & $11.8 \mathrm{~b}$ \\
\hline
\end{tabular}

* Within each trait, means followed by the same letter did not differ among them by the Duncan's test $(\mathrm{p}<0.05)$.

The non-irrigated treatment reached the highest average fruit weight, probably due to reduced production and therefore less competition among the fruits, not differing from $\mathrm{T} 1$ and $\mathrm{T} 3$. There was no difference in average of fruit weight among the irrigated treatments. The ratio obtained in T5 was higher than those obtained in the other treatments, with appropriate value for fruit production for good quality juice, and the irrigated treatments reached close values (POZZAN \& TRIBONI, 2005). The ${ }^{\circ}$ Brix reached at T5 (non-irrigated) was lower than that observed in T2. There was no difference between ${ }^{\circ}$ Brix among irrigated treatments. The values of ratio and ${ }^{\circ} \mathrm{Brix}$ (Table 4) obtained were above those observed in 'Valencia' orange as reported by VILLAS BOAS et al. (2002). The authors did not observe differences in quality traits compared with micro-dripping irrigation when using appropriate water management.

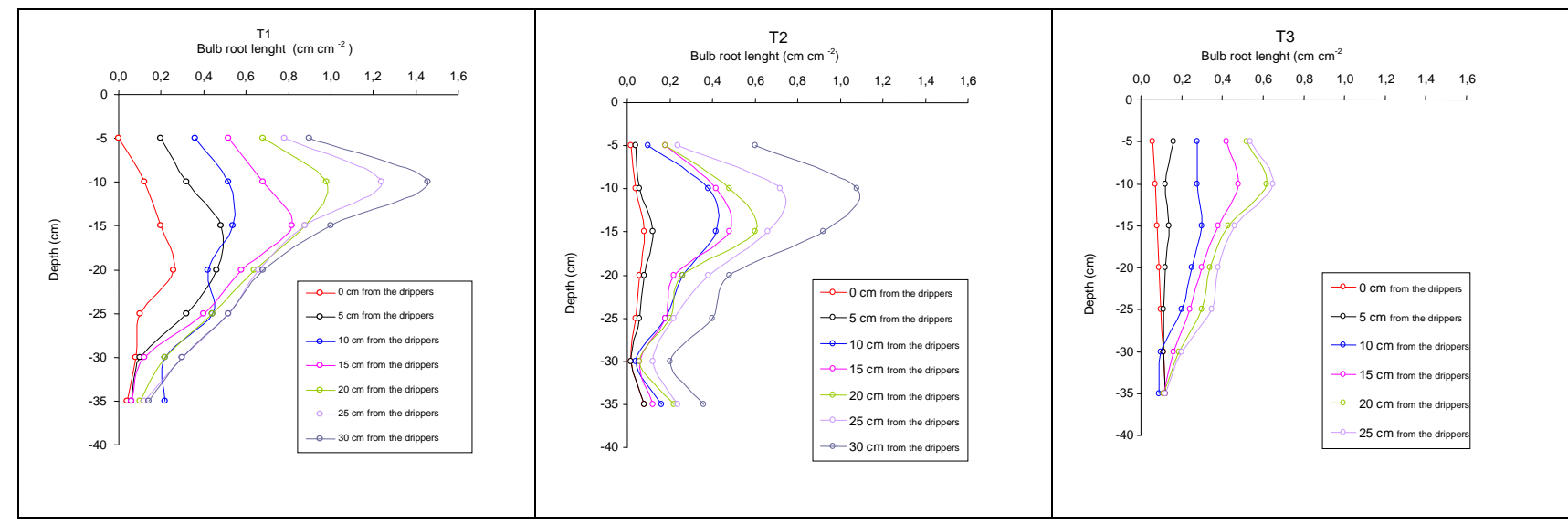

FIGURE 1. Root length average $\left(\mathrm{cm} \mathrm{cm}^{-2}\right)$ of Pêra orange trees grafted on Cleopatra mandarin in wet bulb in different depths and distances of drippers in (T1) one drip line, (T2) two drip lines and (T3) four drip lines per planting row, in different depths, in Casa Branca, state of São Paulo, Brazil.

\section{CONCLUSIONS}

Treatment with a lower number of emitters per plant, i.e., a single dripping tube per planting line (T1) showed higher number of roots in the wet bulb compared to T2 and T3. In all treatments evaluated, there was greater concentration of roots from 0.10 to $0.30 \mathrm{~m}$ lateral distance from the dripper. About $80 \%$ of the roots in the wet bulb were found between 0.20 and $0.25 \mathrm{~m}$ deep from the 
surface. Irrigation favored fruit yield of 'Pêra' orange grafted on 'Cleopatra' mandarin in relation to non-irrigated plants in Casa Branca, SP. The different wet areas provided by daily irrigations did not result in differences in yield and fruit quality of 'Pêra' orange grafted on 'Cleopatra' mandarin.

\section{ACKNOWLEGMENT}

- To Jaraguá Agrícola Fertilizantes Solúveis.

\section{REFERENCES}

ABREU, F.L.G; SALVIANO, A.A.C. Sistema radicular de três porta-enxertos para lima ácida 'Tahiti' no estado do Piauí. Semina: Ciências Agrárias, Londrina, v.28, n.2, p.187-194, 2007.

ALLEN, R.G.; PEREIRA, L.S.; RAES; D.; SMITH, M. Crop evapotranspiration - gidelines for computing crop water requirements. Roma: FAO, 1998. 300 p. (Irrigation and Drainage, Paper 56).

ALVES JUNIOR, J.; LOURENÇÃO, M.S.; SILVA, T.J.A.; SILVA, C.R.; FOLEGATTI, M.V. Distribuição do sistema radicular de plantas jovens de Lima ácida 'Tahiti' sob diferentes níveis de irrigação. Irriga, Botucatu, v.9, n.3, p.270-281, 2004.

BARBOZA JUNIOR, C.R.A.; FOLEGATTI, M.V.; ROCHA, F.J.; ATARASSI, R.T. Coeficiente de cultura da lima-ácida tahiti no outono-inverno determinado por lisimetria de pesagem em Piracicaba - SP. Engenharia Agrícola, Jaboticabal, v.28, n.4, p.691-698, 2008.

BARRETO, G.B.; RODRIGUEZ, O.; REIS, A.J.; ARRUDA, F.B. Irrigação de citros. Campinas: Instituto Agronômico, 1976. 17 p. (Boletim Técnico, 35).

CASTAÑER, M.A. Riego por goteo en cítricos. Madrid: Ediciones Mundi-Prensa, 1993.142 p.

COELHO, E.F.; OLIVEIRA, F.C.; ARAÚJO, E.C.E.; VASCONCELOS, L.F.L. Distribuição de raízes de laranja 'Pera' sob sequeiro e irrigação por microaspersão em solo arenoso. Pesquisa Agropecuária Brasileira, Brasília, v.37, n.5, p.603-611, 2002.

COELHO, E.F.; OLIVEIRA, A.S.; MAGALHÃES, A.F.J. Irrigação e fertirrigação em citros. Cruz das Almas: Embrapa, 2000. 23 p. (CNPMF, Circular Técnica, 38.)

FAO. Statistical Yearbook 2005-2006. Disponível em: <http:www.fao.org/. Acesso em: 19 nov. 2007.

FARES, A.; BUSS, P.; DALTON, M.; EL-KADI, A.I.; PARSONS, L.R. Dual field calibration of capacitance and neutron soil water sensors in a shrinking-swelling clay soil. Vadose Zone Journal, Madison, v.4, p.1390-1399, 2004.

FNP. CONSULTORIA \& COMÉRCIO. Agrianual 2007: anuário estatístico da agricultura brasileira; citros. São Paulo: FNP, 2007. p.277-313.

GENUCHTEN, M.TH. Van. A closed-form equation for predicting the hydraulic conductivity of unsaturated soils. Soil Science of Society America Journal, Madison, v.44, p. 892-898, 1980.

MARSH, B.B. Measurement of length in random arrangements of lines. The Journal of Applied Ecology, Oxford, v.8, n.1, p.265-267, 1971.

MEDINA, C.L.; RENA, A.B.; SIQUEIRA, D.L.; MACHADO, E.C. Fisiologia dos citros. In: MATTOS JUNIOR, D.; DE NEGRI, J.D.; PIO, R.M.; POMPEU JUNIOR, J. Citros. Campinas: Instituto Agronômico e Fundag, 2005. p.147-195.

MORGAN, K.T.; OBREZA, T.A.; SCHOLBERG, J.M.S.; PARSONS, L.R.; WHEATON, T.A. Citrus water uptake dynamics on a sandy Florida Entisol. Soil Science Society of America Journal, Madison, v.70, p.90-97, 2006.

PARSONS, L.R.; WHEATON, T.A. Irrigation management and citrus tree response in a humid climate. HortScience, Alexandria, v.35, p.1043-1045, 2000. 
PIMENTEL-GOMES, F.; GARCIA, C.H. Estatística aplicada à experimentos agronômicos e florestais: exposição com exemplos e orientações para uso de aplicativos. Piracicaba: FEALQ, 2002. 309 p.

PIRES, R.C.M.; LUCHIARI, D.J.F.; ARRUDA, F.B.; MOSSAK, I. Irrigação. In: MATTOS JUNIOR, D.; DE NEGRI, J.D.; PIO, R.M.; POMPEU JUNIOR, J. Citros. Campinas: Instituto Agronômico e Fundag, 2005. p.369-408.

POMPEU JUNIOR, J. Porta-enxertos. In: MATTOS JUNIOR, D.; DE NEGRI, J.D.; PIO, R.M.; POMPEU JUNIOR, J. Citros. Campinas: Instituto Agronômico e Fundag, 2005. p.61-104.

POZZAN, M.; TRIBONI, H.R. Colheita e qualidade do fruto. In: MATTOS JUNIOR, D.; DE NEGRI, J.D.; PIO, R.M.; POMPEU JUNIOR, J. Citros. Campinas: Instituto Agronômico e Fundag, 2005. p.801-822.

QUAGGIO, J.A.; MATTOS JUNIOR, D.; CANTARELLA, H. Manejo da fertilidade do solo na citricultura. In: MATTOS JUNIOR, D.; DE NEGRI, J.D.; PIO, R.M.; POMPEU JUNIOR, J. Citros. Campinas: Instituto Agronômico e Fundag, 2005. p.483-507.

RAIJ, B. VAN; CANTARELLA, H.; QUAGGIO, J.A.; FURLANI, A.M.C. Recomendações de adubação e calagem para o Estado de São Paulo. 2.ed. Campinas: Instituto Agronômico, 1997. $285 \mathrm{p}$.

SAA/CATI/LUPA - Secretaria da Agricultura e Abastecimento, Coordenadoria de Assistência Técnica Integral. Projeto LUPA. Campinas, 2009.

SHALHEVET, J.; LEVY, Y. Citros trees. In: STEWART, B.A.; NIELSEN, D.R. (Ed.). Irrigation of agricultural crops. Madison: Series Agronomy, 1990. p.951-986.

SMAJSTRLA, A.G.; KOO, R.C.J. Effects of trickle irrigation methods and amounts of water applied on citrus yields. Proceedings of the Florida State Horticultural Society, Tallahassee, v.97, p.3-7, 1984.

SOUZA, M.J.H.; RAMOS, M.M.; SIQUEIRA, D.L.; COSTA, L.C.; LHAMAS, A.J.M.; MANTOVANI, E.C.; CECON, P.R.; SALOMÃO, L.C.C. Produção e qualidade dos frutos da limeira ácida 'Tahiti' submetida a diferentes porcentagens de área molhada. Revista Brasileira de Engenharia Agrícola e Ambiental, Campina Grande, v.7, n.2, p.245-250, 2003.

TENNANT, D. A test of a modified line intersect method of estimating root lenght. The Journal of Ecology, v.63, n.3, p.995-1001, 1975.

TESTEZLAF, R.; COLETTI, C.; MATSURA, E.E. Distribuição de raízes da laranja 'Valência' irrigada por autopropelido. Pesquisa Agropecuária Brasileira, Brasília, v.42, n.6, p.905-908, 2007.

VILLAS BOAS, R.L.; MORAES, M.H.; ZANINI, J.R.; PAVANI, L.C.; CAMARGO, D.A.; DUENHAS, L.H. Teores de nutrientes na folha, qualidade do suco e massa seca de raízes de laranja-'Valência' em função da irrigação e fertirrigação. Revista Brasileira de Fruticultura, Jaboticabal, v.24, n.1, p.231-235, 2002.

ZANINI, J.R.; PAVANI, L.C.; SILVA, J.A.A. Irrigação em citros. Jaboticabal: Funep, 1998. 35 p. (Boletim n.7.) 